\title{
Assessment of Colony Carrying Capacity and Factors Responsible for Low Production and Productivity of Beekeeping in Horro Guduru Wollega Zone of Oromia, Ethiopia
}

\author{
Kibebew Wakjira, Alemayehu Gela \\ Oromia Agricultural Research Institute, Holeta Bee Research Center, Holeta, Ethiopia \\ Email address: \\ wkibebew@gmail.com (K. Wakjira)
}

\section{To cite this article:}

Kibebew Wakjira, Alemayehu Gela. Assessment of Colony Carrying Capacity and Factors Responsible for Low Production and Productivity of Beekeeping in Horro Guduru Wollega Zone of Oromia, Ethiopia. International Journal of Natural Resource Ecology and Management. Vol. 4, No. 1, 2019, pp. 14-21. doi: 10.11648/j.ijnrem.20190401.13

Received: December 26, 2018; Accepted: January 20, 2019; Published: February 13, 2019

\begin{abstract}
The study was conducted in Horro Guduru Wolega Zone of Oromia region, Ethiopia in view of investigating colony carrying capacity and prime factors responsible for the low production and productivity of beekeeping in the area. Individual questioner survey, focus group discussions and field assessment were used to collect the relevant data. Moreover, data on suitable land size for beekeeping, seasons and frequency of honey harvest, months of dearth period for colonies, honey potential of the area, number of colonies in one apiary and other issues were collected. Personal observations were also made to the apiary management of the beekeepers. The study revealed that out of 820,956 ha land mass of the zone, about $59 \%$ was found to be with the highest potential for beekeeping with the remaining portion with medium potential. Two major honeyharvesting seasons with average frequency of 1.66 times and two months long dearth period in between the two seasons were identified. Estimated honey reserve potential of the zone is about 89.2 thousand tons/year with colony carrying capacity of 520 bee colonies per single apiary. However, the average number of bee colonies managed per apiary is found to be 260 indicating the overall ratio of actual existing colonies to the carrying capacity of an apiary is 0.5 . From this analysis, current average honey production from traditional transitional and modern were found to be $3.5,14.6$ and $21.0 \mathrm{~kg} / \mathrm{colony} / \mathrm{year}$, respectively with pulled average of $10.6 \mathrm{~kg} /$ colony/year in the study area. With the current bee colony holding size and production level, each beekeeper produces about $244 \mathrm{~kg} / \mathrm{year}$, while it has a possibility of achieving $700 \mathrm{~kg}$ honey per year. From this, the annual yield loss per individual beekeeper can be estimated to $460 \mathrm{~kg}$ honey which can further explored to over $\$ 820$ financial loss. Bee colony miss-management is identified as fundamental major cause of low production and productivity of beekeeping in the study area than the carrying capacity of individual apiary. It is recommended from this study that beekeepers should follow the standard apiary setting to utilize the production potential of their beekeeping endeavor.
\end{abstract}

Keywords: Colony Carrying Capacity, Flowering Calendar, Horro Guduru Wollega and Honey Yield Potential

\section{Introduction}

Having favorable environmental conditions for growth of diversified natural vegetation and cultivated crops, Ethiopia is one of the best areas in the world for beekeeping. Apiculture is one of the agricultural subsectors that most suits the livelihood of rural community in an immense benefit in contributing significantly to income generation and diversification, enhance crop production though pollination, create jobs for landless youths, sustain ecosystem conservation and rehabilitation. In general, beekeeping has positive impacts on food security and environmental stability. As one of the most important economic activities for rural communities in Ethiopia, approximately one out of ten rural households keeps honeybees [1]. According to [2], there are estimated 6.2 million colonies in Ethiopia, of which $90 \%$ are kept in traditional methods. These colonies are managed by about 1.7 million farm households, who are keeping bees as a means of additional income generation [3]. The production 
potential of honey and beeswax is 500,000 and 50000 tons of honey and beeswax, respectively [4]. Therefore, beekeeping in Ethiopia is one of the few sectors that have the most inclusive ability to achieve transformation and growth across all categories of rural households $[1,5]$. However, the current actual production from managed bee colonies is limited to 53,000 and 5000 tons of honey and beeswax per year in that order, which is nearly $10 \%$ of the estimated potential [2]. This indicates that the production and adhering benefits being obtained from this subsector is not commiserating with the existing potential.

Oromia Regional State is one of the potential beekeeping regions of Ethiopia. Horro Guduru Wollega zone is among the 20 administrative zones found in Oromia region comprising 11 districts. Three of the study districts, namely Guduru, Hababo Guduru and Horro, are located in the zone, where especial focus is given for this study. These districts are commonly covered with natural vegetations, shrubs, annual and perennial crops suitable for beekeeping and honey production.

Despite the presence of great opportunities, beekeeping in Horro Guduru Wolega zone is yet underutilized compared to the area's potential. This can be attributed to several factors of which, lack of knowledge on colony carrying capacity, inappropriate stocking and miss management of bee colonies irrespective to the hive type, lack of awareness on flowering calendar of available bee forges in the area and lack of awareness on major and minor honey flow seasons in line with flowering calendar of the area are some of major factors. However, there was no report which specific factor (s) are contributing to the low production and productivity of beekeeping in the study area. This study was therefore, carried out to identify the underpinning factors responsible for low production and productivity of beekeeping and assess the colony carrying capacity of the beekeeping resource of the study area.

\section{Methodology}

\subsection{Description of the Study Area}

The assessment and data collection areas are located between 037o 04.08' to 03o 06.45' E and 09o 02.11' to 09o $42.45^{\prime} \mathrm{N}$, distributed in three representative districts, namely Guduru, H/Guduru and Horro of Horro Guduru Wollega zone of Oromia Regional State, Ethiopia. The districts were purposively selected for the study based on beekeeping potential and accessibility.

The climate of the area is humid subtropical, with noticeable dry winters and very rainy summers by traditional classification. The mean annual temperature is $22^{\circ} \mathrm{C}$ with the range extends between $12^{\circ} \mathrm{C}$ and $32^{\circ} \mathrm{C}$. The pluviometric precipitation varies from $500 \mathrm{~mm}$ to $2,750 \mathrm{~mm}$ with the average rainfall of $1625 \mathrm{~mm}$ and relative humidity of the air remains close to $60 \%$ (from the current data).

\subsection{Study Approach}

For the selection of data collection sites, agro-ecological conditions, available resource (bee forage) and local land use patterns were considered (Figure 1). Based on the secondary information about the study zone, three Peasant Associations (PAs) were systematically selected from each sample districts and a total of 9 PAs were covered for data collection. An average of about 35 respondents (individual beekeepers) was contacted for household survey per selected district and a total of 110 individuals were interviewed for data collection. The respondents were selected based on their experience in beekeeping, knowledge on locally available honeybee forages and honeybee colonies ownership.

\subsection{Sampling Design}

A stratified sampling procedure was followed starting at Zone level with the final sampling unit being a household. Districts were taken to be the primary sampling units, PAs were considered as the secondary sampling units, Enumeration areas (PA zones) were taken to be the tertiary sampling units and the beekeepers were taken as final sampling units. PAs were purposively selected with the sample enumeration areas and respondents from each area selected based on the existing experience on beekeeping.

\subsection{Data Collection on Bee Forages Distribution, Density and Flowering Period}

Data collection was done through beekeepers and institutional interviews, field assessment and focus group discussions. Well-developed questionnaires and checklists were used to ensure the collection of relevant qualitative and quantitative data. Accordingly, data on: land use patterns, floral diversity, flowering time and duration, honey harvesting seasons and honey types were collected for analysis. Personal observations were also made to the apiary management systems of some beekeepers to take representative views through taking picture records. Primary data were collected from direct beneficiaries through key informant interviews and group discussions. Secondary data were collected from local government offices: office of Agriculture and natural resources, Land Administration offices, office of livestock and Fishery resources and local NGOs.

\subsection{Colony Carrying Capacity Determination}

In order to determine the optimum colony carrying capacity of the area, the following assumption was considered: A colony consumes from 60 to $200 \mathrm{~kg}$ honey per year for all the life activities Chaudhary 2009 quoted in [6]. By assuming the annual requirement of all colony groups (weak to strong) for survival, for brood rearing and as fuel for forages to be the mean of the minimum and maximum, a colony can consume $130 \mathrm{~kg}$ to give whatever surplus honey yield for the beekeeper per year. Based on this rough estimation and assuming that the average annual honey yield 
per colony from traditional, transitional and box hives, respectively are: 12,30 and $50 \mathrm{~kg} /$ year. Adding $130 \mathrm{~kg}$ to these honey yield amounts, potential honey per colony from the area would be 142,160 , and $180 \mathrm{~kg}$, respectively.

To estimate colony carrying capacity per apiary, economical flight range (radius, $\mathrm{r}$ ) of $2 \mathrm{~km}$ assumed for worker bees from their nest [7]. Accordingly, workers of a colony at one site can economically forage and provide surplus honey from a total area of $12.6 \mathrm{~km}^{2}$ (that can be calculated by the formula $\mathrm{A}=\pi \mathrm{r} 2$ ), which is equivalent to 1260 ha. According to [8] average potential usable honey reserve value from forest cover and non-arable land assumed to be $84 \mathrm{~kg} / \mathrm{ha}$ and usable honey potential reserve value from different crops and melliferous weeds across cereals (arable land) assumed to be $24 \mathrm{~kg} / \mathrm{ha}$. Therefore, an apiary established in forest and/or non-arable land will have 84 $\mathrm{kg} / \mathrm{ha} * 1260 \mathrm{ha}=105,840 \mathrm{~kg}$ honey reserve, while an apiary established in arable land will have $24 \mathrm{~kg} / \mathrm{ha} * 1260 \mathrm{ha}=$ $30,240 \mathrm{~kg}$ honey reserve with the expected commercial yield indicated earlier. These results, of honey yield assumption were used for calculating optimum number of colonies that can be stocked per apiary under different land use patterns.

\subsection{Data Analysis}

All the collected data were properly coded and key was prepared for each code. Data were then entered to the software and analyzed by using SPSS version 20.0. Descriptive analysis, which included mean, standard deviations of the mean, percentages as well as descriptive graphs and tables were used with respect to the given variables. Detailed calculations on the structure of the major honey source plants were conducted and potential honey reserves were identified and further explored to financial loss for the study area.

\section{Results and Discussions}

\subsection{Land Allocation and Floral Diversity of the Study Areas}

The major portion of the study area belongs to the forest covered and non-arable lands. According to the information collected from different offices of the zone, the forest covered and non-arable lands out of 820,956 ha total land mass of the zone is 482,677 ha, indicating about $59 \%$ of the land mass of the area is with huge honey potential (Table 1).

Table 1. General information about land allocation patterns of Horro Guduru Wollega zone and the three districts.

\begin{tabular}{ll}
\hline Type or land pattern & Area (ha) \\
\hline Total land area & 820,956 \\
Total arable land & 338,279 \\
Non-Arable land & 272,373 \\
Forest cover & 210,304 \\
\hline
\end{tabular}

The main forest covered and non-arable areas of the study zone is herbaceous, shrubs and trees with potential nectar and pollen sources plant species. Some of the identified abundant potential honey source bee forage plants include: Guizotia scabra, Guizotia abyssinica, Vernonia amygdalina, Justicia schiperiana, Syzygium guineense, Croton macrostachyus, Schefflera abyssinica, Albizia gummifera, Eucalyptus globules, Eucalyptus camaldulensis, Dombeya torrida, Combretum molle, Acacia spp (like A. abyssinica, A. mellifera, A. albida etc.), Trifolium ruppellianum, Bidens prestinaria, Acanthus pubescens, Carissa edulis, Grewia bicolor,Vernonia rueppellii, Apodytes dimidiate, and Cordia africana-found distributed over the total area of 482,677 ha.

The remaining significant area (338,279 ha) is occupied by cultivated melliferous species like Guizotia abyssinica, Vicia faba, Pisum sativum, Zea mays, Eucalyptus globulus, Eucalyptus camaldulensis, Grevillea robusta etc. of which some of them are known to produce large quantity of nectar [9].

\subsection{Honey Bee Flora Distribution and Abundance}

Presence and distribution of honeybee flora around apiary is very important for beekeeping. In this regard, all the assessed study area had a huge potential in terms of bee forage to sustain large number of bee colonies (Table 2). Some of major source of special honey plants throughout the study area include: Guizotia spp., Vernonia amygdalina, Syzgium guineense, Croton macrostachyus, Pouteria adolfifriederici, Schefflera abyssinica etc. and in some lowland portion of the zone: Combretum molle, Sesamum orientale, Terminalia brownii, Sida schimperiana and unidentified Cinii and Dhandhansa. According to $[9,10]$ these plants are also known honey sources in many parts of Ethiopia as well.

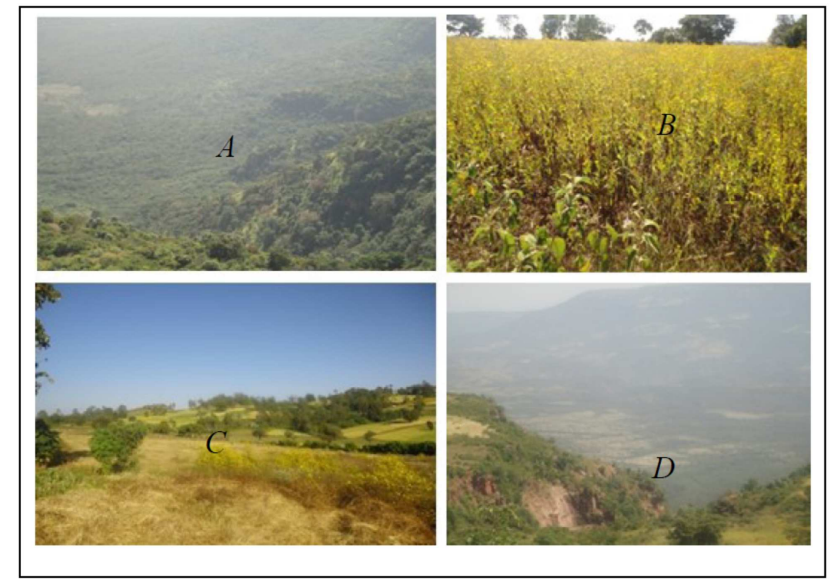

Figure 1. Land use patterns and example of forest $(A)$, arable ( $B$ and $C$ ) and non-arable (D) lands in the study districts areas in Horro Guduru Wollega zone.

\subsection{Major Honey Types and Expected Yield from the Area}

From the assessment of the area, there are more than 20 species of plants, which can provide nectar and pollen, but only 6 honey types were reported by the respondents of the area. The honey types in the area are named after the major (dominant) plant species recorded during the survey from the area (Figure 2). Among the reported honey types, Guizotia accounts the biggest portion, while Cinni accounts the 
smallest quantity. From Figure 3, the total expected commercial honey from the current analysis is 7582.6 tons per year. Therefore, according to the respondent's view, the amounts of potential honey expected by type from the area were: Guizotia -2890.9 t, Vernonia- 1343.7 t, Syzygium555.5 t, Cinni - 412.9 t, Dhandhansa- 465.4 t and mixed flora $1914.2 \mathrm{t}$.

Table 2. Honey bee flora distribution abundance in different agro-ecological zones of the study area with their abundance rank.

\begin{tabular}{|c|c|c|}
\hline \multicolumn{3}{|c|}{$\begin{array}{l}\text { Distribution of the plants across different agro ecological zones the } \\
\text { study area }\end{array}$} \\
\hline Abundance rank & Species & Honey type \\
\hline $1^{s t}$ & Guizotia s spp & $\begin{array}{l}\text { Mono floral honey } \\
\text { source }\end{array}$ \\
\hline $2 n d$ & Vernonia amygdalina & $\begin{array}{l}\text { Mono floral honey } \\
\text { source }\end{array}$ \\
\hline $3 r d$ & Syzygium guineense & $\begin{array}{l}\text { Mono floral honey } \\
\text { source }\end{array}$ \\
\hline 4th & Cinii (unidentified) & $\begin{array}{l}\text { Mono floral honey } \\
\text { source }\end{array}$ \\
\hline 5 th & Dhandhansa (unidentified) & $\begin{array}{l}\text { Mono floral honey } \\
\text { source }\end{array}$ \\
\hline 6 th & Croton macrostachyus & $\begin{array}{l}\text { Mono floral honey } \\
\text { source }\end{array}$ \\
\hline 7 th & Pouteria adolfi-friederici & Mixed honey sources \\
\hline 8 th & Eucalyptus spp & Mixed honey sources \\
\hline 9th & Schefflera abyssinica & Mixed honey sources \\
\hline 10th & Combretum molle & Mixed honey sources \\
\hline 11th & Sesamum orientale & Mixed honey sources \\
\hline 12 th & Sida schimperiana & Mixed honey sources \\
\hline 13th & Terminalia brownii & Mixed honey sources \\
\hline
\end{tabular}

This estimation is possible with the frequency of two honey harvesting seasons as per the floral calendar of the area. But analysis of the frequency of the area indicated that honey is harvested only 1.66 times (Table 4 ). From this fact it is possible to estimate that $17 \%$ of the potential honey yield is lost due to low frequency of honey harvesting. From the drawn floral calendar (Table 3) of the area, there is a possibility of producing at least three times using improved techniques and technologies. Development actors and beekeepers will be able to use this information much more efficiently than following the current traditional approach by specifying the contribution of major available bee forages at least in the study area and other similar agro ecologies.

\subsection{Floral Calendar of the Study Areas}

In all the study areas, high availability of honeybee forage plants was noted to provide the honeybee colonies with ample nectar and pollen at two distinct time of the year (from September to November, first season and from Aril and June, second season) (Table 3). Similarly, in many parts of the country, majority of similar plants in different floristic regions produce flower in these two periods of the year [911]. As a result, these seasons give an opportunity for beekeepers to prepare their colonies for honey production. There are also major honey source plants with more than one flowering calendar like Eucalyptus camaldulensis and Cordia africana. These plants are found in abundance and have large distribution areas in the study zone and this is an opportunity if properly utilized.

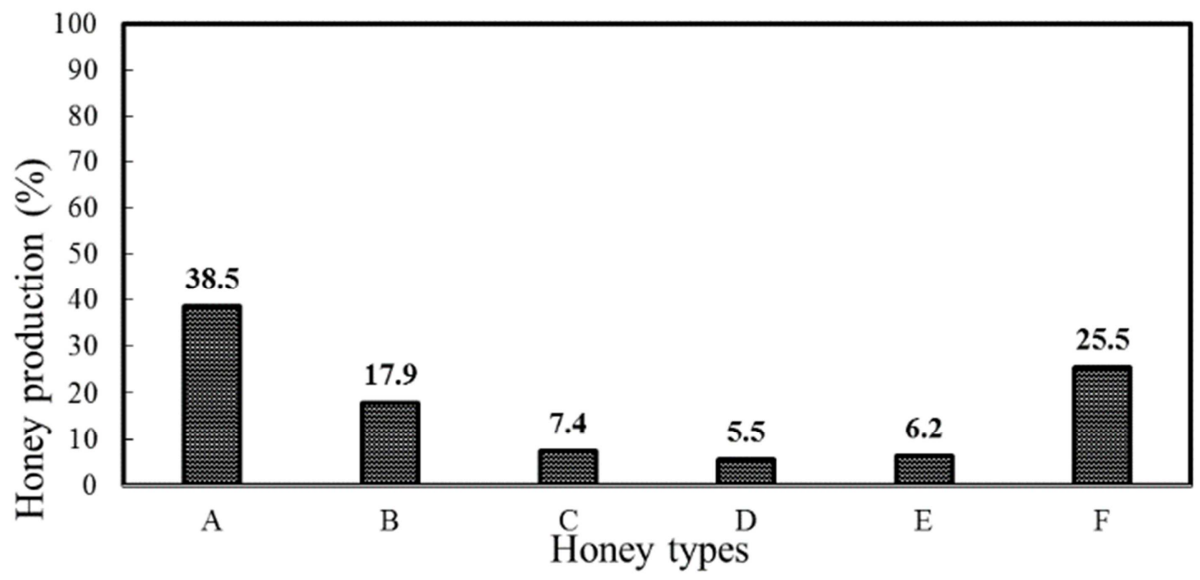

Figure 2. Honey types A (GUIZOTIA), B (VERNONIA), C (SYZYGIUM), D (CINNI), E (DHANDHANSA) and F (MIXED FLORA) from the area. Honey naming is as proposed by the respondents and production percentage is calculated from potential honey reserve of the area.

\subsection{Honey Harvesting Seasons of the Study Areas}

From the flowering calendar, it is possible to clearly observe that there are two major honey-harvesting seasons. The first major honey harvesting time is in the month of November with the possibility of harvesting honey in late December and early January with planned colony management. The second honey harvesting is in between the moths of May and June. Information collected from beekeepers also indicated that there are two seasons with major and minor honey harvesting in a year in the area. However, there are variations among the sampled districts in terms of defining the major and minor honey harvesting months and also the frequency of honey harvesting (Table 4). The result of the survey shows that even though there is a possibility to harvest honey at least twice a year, the beekeepers are not fully utilizing the opportunity. This is one factor for the low production of beekeeping in the study area. 
Table 3. Flowering calendar of major bee flora of the Horo Guduru Wolega zone. Months starts with September (S) and end with August (A). Dark yellow shaded part of the table shows months in which the pants are in flowering time.

\begin{tabular}{|c|c|c|c|c|c|c|c|c|c|c|c|c|c|}
\hline \multirow{2}{*}{ Plant local name } & \multirow{2}{*}{ Plant scientific name } & \multicolumn{12}{|c|}{ Flowering period (months) } \\
\hline & & $\mathbf{S}$ & O & $\mathbf{N}$ & D & $\mathbf{J}$ & $\mathbf{F}$ & M & $\mathbf{A}$ & $\mathbf{M}$ & $\mathbf{J}$ & $\mathbf{J}$ & $\mathbf{A}$ \\
\hline siddisa & Trifolium ruppellianum & & & & & & & & & & & & \\
\hline Salixii & Sesamum orientale & & & & & & & & & & & & \\
\hline Keelloo & Bidens prestinaria & & & & & & & & & & & & \\
\hline Harooressa & Grewia bicolor & & & & & & & & & & & & \\
\hline Tuufoo & Guizotia scabra & & & & & & & & & & & & \\
\hline Nuugii & Guizotia abyssinica & & & & & & & & & & & & \\
\hline Daannisa & Dombeya torrida & & & & & & & & & & & & \\
\hline Waddeessa & Cordia africana & & & & & & & & & & & & \\
\hline Dhumuugaa & Justicia schimperiana & & & & & & & & & & & & \\
\hline Kosomuu & Acanthus pubescens & & & & & & & & & & & & \\
\hline Daannisa & Combretum molle & & & & & & & & & & & & \\
\hline Barzafii & Eucalyptus camaldulensis & & & & & & & & & & & & \\
\hline Bahaa & Apodytes dimidiata & & & & & & & & & & & & \\
\hline Eebicha & Vernonia amygdalina & & & & & & & & & & & & \\
\hline Reejjii & Vernonia ssp & & & & & & & & & & & & \\
\hline Agamsa & Carissa edulis & & & & & & & & & & & & \\
\hline Laftoo & Acacia spp & & & & & & & & & & & & \\
\hline Gatamaa & Schefflera abyssinica & & & & & & & & & & & & \\
\hline Baddeessaa & Syzygium guineense & & & & & & & & & & & & \\
\hline Bakkaniisa & Croton macrostachyus & & & & & & & & & & & & \\
\hline Bargamoo adii & Eucalyptus globulus & & & & & & & & & & & & \\
\hline Dabaqqaa & Terminalia brownii & & & & & & & & & & & & \\
\hline Dhandhansa & unidentified & & & & & & & & & & & & \\
\hline Cinii & unidentified & & & & & & & & & & & & \\
\hline Mokkoo Dhala & unidentified & & & & & & & & & & & & \\
\hline Ajata & unidentified & & & & & & & & & & & & \\
\hline Kottee & Sida schimperiana & & & & & & & & & & & & \\
\hline
\end{tabular}

\subsection{Bee Forage Scarcity Period (Dearth Period)}

Although there are ample honeybee floras throughout the year, in the months of February to March and from July to August, there is shortage of bee forage sources (Table 3). These months were identified as dearth period in which there is no or little bee forage in the study area as reported by the respondents almost similar to season of flower dearth seasons (data not presented). One of these identified bee forage scarce period (February to March) in current study is in agreement with the report of $[9,10]$ in most Ethiopian areas. During these dearth periods, bees exhaust their reserve food and abscond from their nest.
From the drawn flowering calendar (Table 3), it is clear that February and March months are moments of extreme dearth as there is no flowering plant reported in the study area and hence colonies can be seriously affected unless supplementary feed is provided. Although, months of July and August colony are reported as death period, there are still some flowering forages. Nevertheless, the problem will be heavy rain during these months which may wash pollen and dilute nectar resulting in forage scarcity condition for the bees. Therefore, providing supplementary feed will also help in reducing colony absconding during this time as well.

Table 4. Honey harvesting months in the sampled districts and overall study area.

\begin{tabular}{lllll}
\hline \multirow{2}{*}{ Districts } & \multirow{2}{*}{} & Honey harvesting months & & \multirow{2}{*}{ Frequency of honey harvest per year } \\
\cline { 2 - 5 } & & Major harvesting months & Minor harvesting months & \\
\hline Guduru & 41 & November & June & 1.74 \\
Hababo Guduru & 34 & November & May & 1.77 \\
Horro & 35 & May & Mid December & 1.46 \\
Overall & 110 & November & May to June & 1.66 \\
\hline
\end{tabular}

\subsection{Honey Reserve and Production Potential of the Study Area}

Figure 3 shows major bee forage land types and their potential contribution to the total estimated honey production. In this calculation, estimation has been carried out by considering the contribution of each major plant species for honey production in two seasons. When calculating the first season potential, all recorded bee forage (both major and minor) sources that can give flower during this time were taken into account as contributors for a single honey harvest. When calculating the second season, only 
areas covered by forest and non-arable land were considered as cultivated crops assumed to be nonexistent during this season. Horticultural crops and irrigable land can contribute negligible amount with the current information obtained as the coverage is very insignificant to affect the relevance of current calculation at least for the coming few years.

By assuming $84 \mathrm{~kg} /$ ha honey potential reserve for the forest and non-arable areas and $24 \mathrm{~kg} / \mathrm{ha}$ for the arable areas, the calculated total honey reserve is 89208.3 tons per year of which 7582.6 tons is possible commercial production. But from the current study, an apiary was found to hold only 260 bee colonies (Figure 5) with average honey yield of 10.6 $\mathrm{kg} /$ year (Table 7). These figures showed that the total honey production from the area is only about 1806.1 tons.

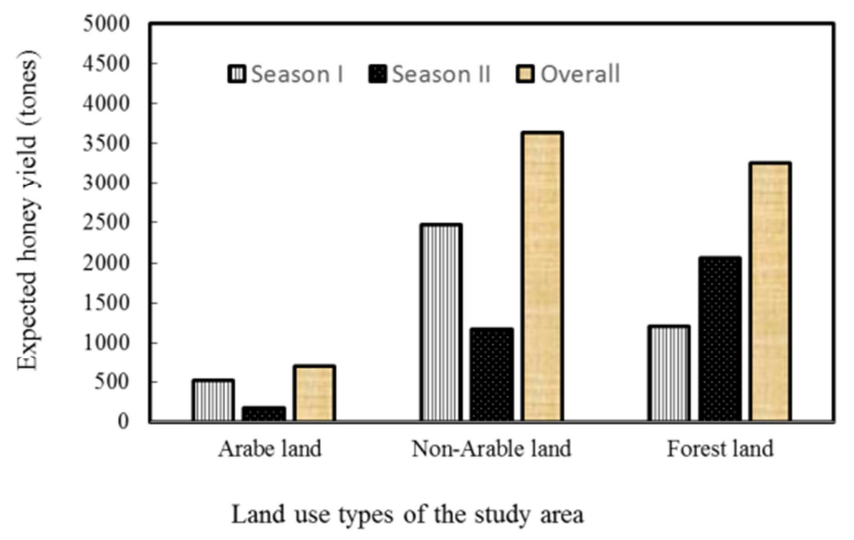

Figure 3. Potential honey reserves of the study zone (Horro Guduru Wollega).

\subsection{Honey Bee Colony Holding Size by Type of Hive Per Beekeeper in the Study Area}

About $60 \%$ of the respondents are keeping their colonies only in traditional beehives (Figure 4) with the colony holding size 31 (Table 5). The domination of traditional beekeeping in the study area can be part of a deep-rooted cultural practice under exercise for generations in different parts of the country [1]-[3]. This traditionally dominated beekeeping practices is an indication for a critical need for more skill development and awareness creation to transform these beekeepers from traditional to improved beekeeping. Of course, high cost and non-affordability of modern beekeeping equipment and the accessories that can be difficult for individual to acquire can also play great role to force the beekeepers to sustain the traditional beekeeping. However, compared to the general $90 \%$ traditional beekeeping level [4] in Ethiopia, 60\% still better. This improvement can be attributed to the intervention by Gurmu Development Association (GDA) and Education for Development Association (EFDA) for the last ten years [12], which probably had helped the beekeepers to transform their beekeeping from traditional system to transitional, modern or mixed types. About, $7 \%$ of the beekeepers in the study area possessed only transitional or modern beekeeping while $33 \%$ of the beekeepers run mixed (all the three beehive) beekeeping type in their apiaries (Figure 4).
Table 5. Number of colonies owned by type of hive per beekeeper in the study area.

\begin{tabular}{ll}
\hline Hive type & Av. colony holding per beekeeper \\
\hline Traditional only & 31 \\
Transitional only & 10 \\
Modern only & 8 \\
Traditional and transitional & 15 \\
Traditional and Modern & 25 \\
All the three type & 23 \\
\hline
\end{tabular}

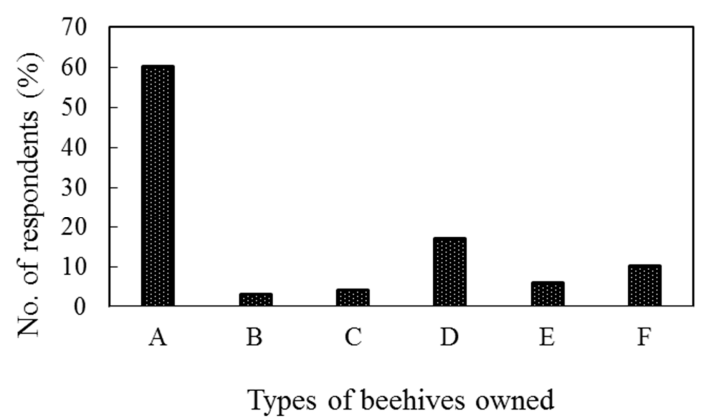

Figure 4. Percentage distribution of honeybee colonies owned by hive types: $A$ (traditional), $B$ (transitional), $C$ (modern), $D$ (traditional and transitional mixed), $E$ (traditional and modern mixed) and $F$ (all the three hive types) in the study area.

\subsection{Optimum Colony Carrying Capacity Per Apiary of the Area}

From the result of the current study, different land use types have different theoretical potential of honey yield for optimum colony carrying capacity per apiary. For optimum colony carrying capacity calculation, average commercial honey harvest per colony of traditional, transitional and modern hives were assumed to be 12,30 and $50 \mathrm{~kg} /$ year. Adding $130 \mathrm{~kg}$ consumed by bees to these commercial honey yield amounts, optimized potential of honey reserve of 142 , 160 and $180 \mathrm{~kg} /$ year, respectively for traditional, transitional, and modern hives from the flora per year was considered. In order to determine the colony carrying capacity per apiary, we used these optimized production potential rate of the different hive types. To establish optimum colony carrying capacity per apiary, first we also need to establish standard for an apiary size. To this end, from the commercial beekeeping point of view, the economical flight radius (r) of honeybees is assumed to be $2 \mathrm{~km}$ [7]. Therefore, colonies at one site can economically forage and provide surplus honey from a total area of $12.6 \mathrm{~km}^{2}$ (that can be calculated by the formula $\mathrm{A}=\pi \mathrm{r} 2$ ), which is equivalent to 1260 ha.

By taking the average potential honey reserve value of 84 $\mathrm{kg} / \mathrm{ha}$ from the forest cover and non-arable land areas and 24 $\mathrm{kg} / \mathrm{ha}$ honey potential reserve from arable land an optimum colony carrying capacity of each apiary was calculated. With this potential rate, the minimum total honey available for the bees in an apiary established in forest and/or non-arable land will be $84 \mathrm{~kg} / \mathrm{ha} * 1260 \mathrm{ha}=105,840 \mathrm{~kg}$. As a result, the optimum number of colonies for example in traditional hives per apiary in such areas is calculated as: Optimum number of colonies in traditional hives $=$ optimum honey yield expected per apiary divided by $142=105840 / 142=745$ colonies. Similarly, to produce optimum honey yield (50 
$\mathrm{kg} / \mathrm{yrs}$./colony) from modern hives in forest covered potential areas per apiary is 588 (Table 6).

From the current analysis, there is a possibility of sustaining about 520 bee colonies in traditional hives per single apiary on average. However, the average number of colonies maintained in each apiary at present are only 260 (Figure 5) indicating only $0.5(50 \%)$ of the existing capacity is utilized. On top of this, the numbers of transitional and modern are very few compared to the dominant traditional beekeeping, indicating huge gap between actual stock and carrying capacity. Therefore, from the study it was proved that colony overcrowding was not a problem; rather it is possible to have additional colonies by properly setting the apiaries.

Table 6. Optimum carrying capacity of an apiary in the study areas for well managed colonies.

\begin{tabular}{|c|c|c|c|c|}
\hline \multirow[t]{2}{*}{ Type of land to be utilized } & $\begin{array}{l}\text { Optimum honey } \\
\text { available }\end{array}$ & \multirow[t]{2}{*}{ Type of hive } & \multirow{2}{*}{$\begin{array}{l}\text { Honey Requirement per } \\
\text { colony (kg) }\end{array}$} & \multirow{2}{*}{$\begin{array}{l}\text { Number of colonies that can be } \\
\text { stocked per apiary }\end{array}$} \\
\hline & per apiary (kg) & & & \\
\hline \multirow{3}{*}{$\begin{array}{l}\text { Forest cover and non-arable } \\
\text { land }\end{array}$} & \multirow{3}{*}{105,840} & Traditional & 142 & 745 \\
\hline & & Transitional & 160 & 662 \\
\hline & & Modern & 180 & 588 \\
\hline \multirow[b]{2}{*}{ Arable land } & \multirow[b]{2}{*}{30,240} & Traditional & 142 & 213 \\
\hline & & Transitional & 160 & 189 \\
\hline \multirow{3}{*}{ All land use types } & \multirow{3}{*}{74,689} & Traditional & 142 & 526 \\
\hline & & Transitional & 160 & 467 \\
\hline & & Modern & 180 & 415 \\
\hline
\end{tabular}

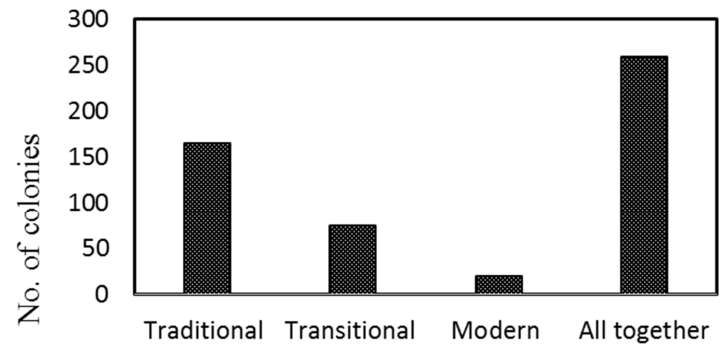

Type of hives used

Figure 5. Number of colonies exists in a given apiary by type from the collected data.

\subsection{Key Factors Responsible for Low Production and Productivity of Bee Keeping}

Despite the fact that there is optimum or bellow optimum colony carrying capacity exist in the locality, production and productivity of the colony is very low (Table 7). This indicates that the problem associated with low production level is not colony overstocking rather it is the way beekeepers manage their colonies. From our field observation, the number of beehives kept under $3 * 10 \mathrm{~m}$ roof in the backyards was more than 100 bee colonies (Figure 6), the condition being similar in almost every village.

Table 7. Amount of total honey produced ( $\mathrm{kg}$ ) per hive type and productivity per hive per year in the study zone. Data was obtained from beekeepers ( $\mathrm{n}=110$ ).

\begin{tabular}{|c|c|c|c|c|}
\hline \multirow{2}{*}{ Hive Type } & \multicolumn{3}{|c|}{ Honey yield obtained per beekeeper/year (kg) } & \multirow{2}{*}{ Av. honey yield per colony (kg) } \\
\hline & Minimum & Maximum & Average & \\
\hline Traditional only & 62 & 155 & 110 & 3.5 \\
\hline Transitional only & 78 & 195 & 146 & 14.6 \\
\hline Modern only & 90 & 244 & 210 & 21.0 \\
\hline Traditional and Transitional & 80 & 150 & 114 & 7.6 \\
\hline Traditional and Modern & 145 & 300 & 225 & 9.0 \\
\hline All the three types & 160 & 700 & 244 & 10.6 \\
\hline
\end{tabular}

As a result, even though the total number of bee colonies in apiary was below the optimum carrying capacity, maintaining more than a maximum of 50 bee colonies under congested roof is hardly recommendable. This is because, the situation can create a difficult condition for colony management, facilitate favorable condition for disease transmission and pest attack. On top of these, congested beehives can facilitate drifting of foragers to only certain beehives and this leads to the deteriorating of the majority of the colonies and only few good performing ones. Therefore, to prevent drifting of the forages and reduce pest and diseases incidence, the minimum distance between two colonized hives should be at least 1.5 meters apart.

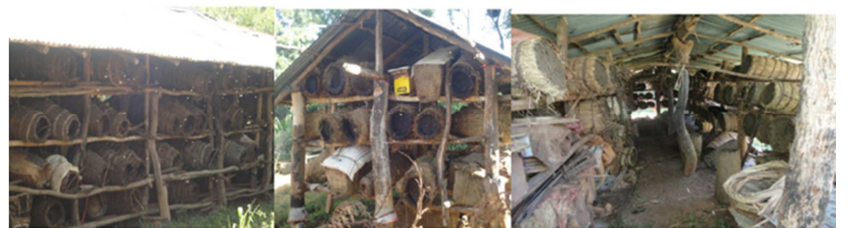

Figure 6. Congested colony setup and miss management.

To substantiate, the effects of congested colony on production and productivity, honey production trend analysis conducted and the result presented in Table 7. From the result of analysis, production of honey per colony in traditional beehive was only $3.5 \mathrm{~kg}$ on average indicating more than 3fold yield loss in the study area. Similarly, the recorded 
production level of honey yield per colony in transitional and modern hives was also less than $50 \%$ of the expected production. This result demonstrated that the total production level of honey/colony/year is very low, contrary to the honey yield potential of the area. Currently, a beekeeper holds 23 bee colonies within all the three hive types and average annual production of $244 \mathrm{~kg} /$ year. But with equal proportion of the three types of hives and same number of colonies, it is possibility for producing about $700 \mathrm{~kg}$ honey per year. From this, the annual yield loss per individual beekeeper can be estimated to $460 \mathrm{~kg}$ honey which can further explored to over $\$ 820$ financial loss. From zonal honey yield potential perspective, the analysis indicated possibility of producing $7,582,600 \mathrm{~kg}$ per year. However, the currently achieved honey yield production is $1,806,100 \mathrm{~kg}$ per year indicting that only about $24 \%$ of the potential was tapped. So, because of mismanagement, and other contributing factors about $76 \%$ of the potential of the area was unutilized. Several reports [1$4,9,11]$ also indicted that the level of production is very low compared to the potential of the country.

\section{Conclusions and Recommendations}

Production and productivity of beekeeping in the study area was found to be very low as compared to the existing potential resources. However, the problem associated with low production level was not colony overstocking rather factors like technical skills associated with colony management were identified as the major obstacles. Low frequency of honey harvesting (only 1.66) was also another factor contributing for low honey production level in the study area.

In order to improve production and productivity, therefore, use of improved management and technologies is very important. For this, training of beekeepers, assuring improved technology supply, building capacity of extension agents and supporting establishment of market places with requisite facilities should be considered in the future development activities for improving honey production, productivity for maximizing the benefit of the target beneficiaries.

\section{Acknowledgements}

The authors are thankful to Gurmu Development Association (GDA) and Education for Development Association (EFDA) Ethiopia, for providing the financial assistance and logistic arrangement. Our special thanks also go to Holeta Bee Research Centre for all the technical support and approval of the activity. Moreover, the authors are indebted to beekeepers, offices of Agriculture and natural resources, Land Administration offices, Livestock and Fishery resources of Horo Guduru Wollega for providing all the necessary information for carrying out this assessment study.

\section{References}

[1] A. Sebsib and T. Yibrah, "Beekeeping Practice, Opportunities, Marketing and Challenges in Ethiopia: Review," J. Dairy Vet. Sci., vol. 5, no. 3, pp. 1-21, 2018.

[2] CSA, "Federal democratic republic of Ethiopia, Central statistical agency. Agricultural sample survey 2016/17, report on Livestock and livestock characteristics," 2017.

[3] D. Paulos, "Ethiopian Honey: Accessing International Markets with Inclusive Business and Sector Development. SNV Ethiopia.," Seas Chang., pp. 1-7, 2012.

[4] 21st to 26th September, 2016," in 5th ApiExpo Africa 2016, 2016, pp. 1-32.

[5] B. Masuku, "Socioeconomic analysis of beekeeping in Swaziland: A case study of the Manzini Region, Swaziland," J. Dev. Agric. Econ., vol. 5, no. 6, pp. 236-241, 2013.

[6] A. Al-Ghamdi, N. Adgaba, A. Getachew, and Y. Tadesse, "New approach for determination of an optimum honeybee colony's carrying capacity based on productivity and nectar secretion potential of bee forage species," Saudi J. Biol. Sci., vol. 23, pp. 92-100, 2016

[7] M. Giovanetti and G. Aronne, "Honey bee interest in flowers with anemophilous characteristics: First notes on handling time and routine on Fraxinus ornus and Castanea sativa," Bull. Insectology, vol. 64, no. 1, pp. 77-82, 2011.

[8] V. N. Kulakov, Melliferous resources of the Russian federation. Moscow, Russia: Russian State Agricultural University-Moscow Timiryazev Agricultural Academy, 2015.

[9] A. Admasu, W. Kibebew, K. Ensermu, and B. Amssalu, Honeybee forages of ethiopia. 2014.

[10] R. Fichtl and A. Adi, Honeybee Flora of Ethiopia. Margraf Verlag, Germany, p. 510. 1994.

[11] G. Yetimwork, T. Berhan, and B. Desalegn, "Honeybee production trend, potential and constraints in Eastern Zone of College Tigray," Agric. Biol. J. North Am., vol. 6, no. 1, pp. 22-29, 2015.

[12] DAMMA, "Developing Apiculture Management and Market Access, Annual Bulletin, 2016,” 2017. 